H. Chernichenko

S. Bespalov

\title{
THEORETICAL APPROACHES TO THE DETERMINATION OF GLOBALIZATION AND THE ESSENCE OF MODERN GLOBALIZATION PROCESSES
}

The article is devoted to the research of theoretical scientific researches on the essence of globalization processes and the concept of "globalization». The author focuses on the vectors of functioning and development of globalization in the world economic science. It is found that scientists are highlighting economic, political and cultural globalization. It is determined that globalization is divided into extensive and intensive according to the directions of development.

The scientific works of prominent economists who study the essence of globalization and globalization processes are analyzed. The analysis is conducted in the framework of differentiation of their views on globalization processes. The author is highlighted the ideas of globalists, alter-globalists, anti-globalists and skeptics.

The basic scientific conceptual approaches to understanding the processes of globalization are outlined. This allowed the author to identify the positive and negative aspects of modern globalization processes. It is concluded that globalization still has a more positive impact on the world, international relations, economy and society than at first sight.

The article notes the lack of unity in the scientific environment of thoughts about globalization and the processes that accompany it.

It is found that there are 4 concepts that explain the nature of globalization processes: the concept of "archaic globalization», the concept of globalization as a modern economic phenomenon, the concept of protoglobalists, and the concept of globalization as some of the temporal properties inherent in world society. Author is analyzed the basic ideas of it.

It is noted that the most frequent scientific debates on globalization took place in the second half of the last century.

The author notes that such uncertainty provides about definition of globalization extensive opportunities for further research into the impact of globalization processes on politics, the economy and the environment.

Keywords: globalization, economy, globalization processes, cultural globalization, concept, globalists, hyperglobalists, skeptics, alterglobalists.

\section{УДК 339.54-049.5}

\section{О. І. Карпенко}

\section{ГЛОБАЛІЗАЦІЯ 4.0: МІЖНАРОДНА ТОРГІВЛЯ ТА НАЦІОНАЛЬНА БЕЗПЕКА}

У статті досліджено ризики міжнародної безпеки, які особливо актуалізувались в умовах четвертої індустріальної революиії, із появою нових технологій (у першу чергу ичифрових, біологічних), вплив яких формує нові виклики для розвитку стану начіональних економік, їх безпеці, довкілля тощзо.

Визначено нові виміри впливу краӥн світу у сучасній системі світового господарства, щзо впливають на трансформацію торговельно-економічної політики країн.

Автором підкреслено, щуо нащіональна безпека кожної краӥни є важливою складовою у системі міжнародної безпеки в иілому, відповідно, наявність спільних 
інтересів визначатимете напрями міжнародного співробітництва краӥн, розвиток інтеграчійної взаємодї між ними. Важлива роль у формування глобальної системи безпеки належить міжнародним організаціям, діяльність яких спрямована на гармонізацію взаємовідносин між краӥнами, трансформацію інтересів кожної країни у спільні (глобальні інтереси).

Автором доведено, щзо у сучасних реаліях розвитку світового господарства ризики посилюються, а колективні засоби врегулювання не спроможні їх вирішити. Посилення ризиків розвитку світового господарства трансформує торговельноекономічні політики краӥн, змінюються інструменти регулювання зовнішньої торгівлі задля забезпечення начіональних інтересів.

Зовнішньоторговельна складова безпеки залежить від ефрективності зовнішньоторговельної діяльності країни, це, у свою чергу, значною мірою визначає умови формування рівня конкурентоспроможності. Достатньо високий рівень конкурентоспроможності $\epsilon$ передумовою формування безпекового середовища. Врахування конкурентних переваг та потенційних напрямів їх посилення дозволить забезпечити зростання рівня ефективності зовнішньоторговельної діяльності, формування достатнього рівня відкритості економіки, оптимального рівня ї̈ спеціалізації в системі міжнародного поділу пращі, що в свою чергу сприятиме підвищенню рівня зовнішньоторговельної безпеки краӥни і визначатиме подальші наукові пошуки автора.

Ключові слова: глобалізація 4.0, міжнародна торгівля, національна безпека, торговельно-економічна політика, глобалізачія.

DOI 10.34079/2226-2822-2020-10-19-48-56

Сучасний індустріалізований світ рухається до суспільства ризику, у цьому суспільстві багатство і розподіл багатства замінюється розподілом ризику. Мова йде про появу нової ризикової та непередбачуваної реальності, у якій визначення природи походження загроз та ризиків, розробка відповідних дій з боку держави є недостатнім для ефективного розвитку національної економічної системи. Посилюється вагомість міждержавної взаємодії та співпраці для спільної протидії ризиковим наслідкам. У суспільстві ризику уникнення небезпек і громадянських загроз може зрештою перевершити економічні питання як основну рушійну силу місцевої, національної та міжнародної політики. Оскільки не існує світового уряду, ринковий ризик не може бути обмежений на національних ринках. 3 іншого боку, жоден національний ринок не може повністю захистити себе від проявів глобалізації.

Дослідження сучасних ризиків міжнародної безпеці особливо актуалізувались в умовах четверта індустріальна революція із появою нових технологій (у першу чергу цифрових, біологічних), вплив яких формує нові виклики для розвитку стану національних економік, їх безпеці, довкілля тощо [15]. Світ став не тільки мультиполярним, а й мультиконцептуальним [9,с.21], руйнівні зміни якого мають пролонговану тривалість, оскільки пов'язані із труднощами у вирішенні етично чутливих питань, таких як права людини, посиленням тиску на багатосторонні механізми врегулювання суперечок, поглиблення залежності між країнами [22], зростанням економічного націоналізму у світовій політиці [16]. Геоекономічна та геополітична напруга у світі постійно зростає, загострення конфронтації між основними гравцями світового ринку (перш за все, США та КНР) ще більше посилює ризиковість глобального середовища.

На необхідність дослідження нових вимірів безпеки звертає увагу Ст.Уолт [20], формуванню ризиків через зміни співвідношення матеріальних та нематеріальних 
ресурсів, які належать країнам, приділяє особливу увагу Г.Моргентау [12]. Нові умови існування світового господарства викликають нові напрями розвитку конфліктів у світовому співтоваристві, дослідженню яких присвячено наукові розробки У.Бека [2]. Цілком логічним $є$ висновок С.Агіра, Н.Армана щодо формування оновленого контексту змістовного наповнення досліджень об'єктів безпеки за нових умов [1].

Мета статті - визначення нових вимірів впливу країн світу у сучасній світового господарства, що впливатиме на трансформацію торговельно-економічної політики країн.

Еволюція наукових пошуків, пов'язаних із визначенням загроз та ризиків існування та розвитку національних економік, відображає зміни, що відбувається у еволюції безпосередньо концепції безпеки - від традиційної (державоцентриської) до сучасних нетрадиційних концепцій. Відповідно до традиційної концепції контекст безпеки мав вимір сили країни шляхом вимірювання військових сил. Тобто безпосередньо інша держава, іiі військова сила спроможна забезпечити перерозподіл сил, ресурсів та влади, що може стати джерелом загроз та конфліктів для національної економіки. Відповідно, інші виміри контексту безпеки, які пов'язані із дослідженнями бідності, міграційних процесів, деградація навколишнього середовища набувають актуальності лише за умов, коли вони спроможні викликати зброєний конфлікт [20]. Однак таке уявлення про загрози та ризики безпеці є недостатнім, відповідно, були спроби поглибити та розширити поняття безпеки від рівня держави до безпеки суспільства, безпеки людини.

Гарантування безпеки - функція кожної держави, оскільки військову безпеку може забезпечити саме держава. Ресурсне забезпечення військової безпеки можливо за умов успішного економічного розвитку, а сама економіка стає джерелом і військової безпеки, і національного багатства у цілому Д.Нанто [13]. Однак методи, які використовують національні уряди задля забезпечення національної безпеки, суттєво відрізняються.

Матеріальні (ресурси, військова сила) та нематеріальні (дипломатія, національний характер) фактори визначають співвідношення сил між країнами, відповідно, більш переважаюча сила спроможна вплинути на це співвідношення, зазначав Г. Моргентау [12,с.201]. Наявність більш переважаючої сили у країни спроможна вплинути на існуючий баланс сил між країнами, що призводить до виникнення конфліктів між країнами. Більш того, посилюючи власну безпеку, уряди країн впливають на послаблення безпеки інших країн через створення відповідних загроз та ризиків (дилема безпеки). У випадку неспроможності забезпечити рівноважний стан у міждержавних взаємовідносинах країни посилюють витрати на забезпечення власної безпеки (у першу чергу це проявляється через збільшення витрат на ВПК, нарощування озброєнь), втрачаючи можливість більш продуктивного використання обмежених ресурсів, а від так і більш ефективного розвитку національної економіки

Інтенсифікація міжнародних відносин суттєво розширили дослідження об’єктів безпеки, який за часи холодної війні був чітко визначений, а за нових умов трансформувався у комплексний та багатовимірний контекст [1,c.107]. Окрім того, загрози безпеці національної економіки можуть з находитись у позадержавній площині. У.Бек виділяє три осі конфлікту в світовому суспільстві ризику [2,с.13-14]: конфлікти екологічних ризиків, які спонтанно генерують глобальні динамічні процеси; глобальні фінансові ризики, які трансформуються від індивідуальних до консолідованих; загрози з боку терористичних мереж.

Таким чином, у сучасній системі міжнародних відносин вплив кожної держави визначається не тільки iï перевагами у військовій силі, а й іншими вимірами іiі впливу у сучасному геопростірі, до яких відносяться економічний потенціал, рівень інноваційного 
та технологічного розвитку, дипломатичний вплив тощо. Цілком логічним є розуміння, що сучасний інструментарій впливу з боку держав не обмежується тільки наявним військовим потенціалом, звідси особливої актуальності набуває досягнення та підтримка балансу сил у світовому господарстві. Баланс сил у сучасні міжнародній системі визначається відповідними правилами та нормами, підкреслює М.Каплан [11], які характеризуються наступним:

1) збільшувати можливості, вести переговори, а не боротися;

2) не стільки боротися, скільки посилювати можливості;

3) припинити боротьбу ніж усунути важливого актора;

4) протистояти будь-який коаліції або окремому актору, що прагнуть прагне зайняти позицію переважання в системі;

5) стримувати суб'єктів, які підписуються наднаціональними організаційними принципами;

6) дозволяти переможеним або обмеженим основним суб'єктам знов повернутись до системи.

Фактично, мова йде про те, що будь-який конфлікт впливатиме на розвиток національної економічної системи. У сфері міжнародного обміну торговельний конфлікт безпосередньо впливає не тільки на сферу зовнішньоторговельної безпеки, а й національної безпеки в цілому. Досліджуючи зв'язок між міжнародною торгівлею та національною безпекою, можна зазначити, що, з одного боку, спостерігається взаємний позитивний влив між ними, а з іншого - можуть існувати суттєві протиріччя, коли задля захисту національної безпеки застосовуються спеціальні торговельні заходи. У свою чергу, наголошує Т.Ілген чим більше зростає взаємозалежність між країнами, тим біль скоріше відбуваються зміни у правилах міжнародного обміну [10, с. 56]. Розширення міжнародної торгівлі сприяє підвищенню національної безпеки. 3 іншої сторони, торговельні санкції негативно впливають на загальний розвиток міжнародної торгівлі, тому їх запровадження має бути тільки у відповідності до міжнародних норм та правил, включаючи угоди СОТ.

Сучасний характер розвитку міжнародної торгівлі свідчить, що у світі протекціонізм посилюється, інструменти, які використовують уряди для захисту національних ринків значно диверсифікувались i набули нових форм [15,21]. Протекціонізм, підкреслює К.Холсті, негативно в цілому впливає як на загальну міжнародну економічну безпеку, так і на національну безпеку, оскільки значно знесилює систему міжнародних економічних відносин [8]. Л.Олвей, Дж.Долден, Р.Келлі [14] визначають, що політика протекціонізму посилює ризики для забезпечення національної безпеки, оскільки спостерігається високий рівень взаємозалежності країн, а від так, національні економіки є більш вразливими, оскільки напрями товарних, ресурсних, капітальних потоків змінюються внаслідок впровадження торговельних обмежень і негативно впливають на зростання ВВП країни.

Національні уряди активно проводять цілеспрямовані політики задля забезпечення більш справедливих результатів розподілу [6], у тому числі використовуючи різноманітні інструменти захисного, стимулюючого, дискримінаційного та рестрикційного характеру, динаміка яких щороку зростає (табл.1) [5].

За даними Global Trade Alert починаючи з листопада 2008 року урядами різних країн було імплементовано понад 17,7 інтервенцій. Найбільш поширеними серед інструментів регулювання стали субсидії (7415), експортні заходи (включаючи експортні субсидіi) (3763), тарифні обмеження (2424) тощо. Найбільшу кількість обмежувальних заходів було застосовано з боку Китаю (2888), США (2089), Німеччини (1684), Індії (1009) тощо. Галузевий аналіз застосування обмежувальних торговельних інструментів виявив, що найбільша кількість захисних інструментів була реалізовано по 
відношенню до продукції металевої та сталеливарної продукції, транспортних засобів, органічної хімії. Як наслідок, світова торгівля стає менш вільною, так, за період с початку 2017 р. і до 15 листопада 2019 р. впроваджені урядами країн торговельні заходи сприяли спотворенню світової торгівлі на 40\%, з яких 23\% припадає на США та Китай [18,с.6].

Таблиия 1

Динаміка застосування обмежувальних та торговельних засобів у світовому господарстві

\begin{tabular}{|r|r|r|c|}
\hline \multicolumn{1}{|c|}{ роки } & всього & обмежувальні заходи & ліберальні заходи \\
\hline 2009 & 1906 & 1451 & 455 \\
\hline 2010 & 1937 & 1387 & 550 \\
\hline 2011 & 2001 & 1423 & 578 \\
\hline 2012 & 2378 & 1711 & 667 \\
\hline 2013 & 2470 & 1785 & 685 \\
\hline 2014 & 2407 & 1745 & 662 \\
\hline 2015 & 2470 & 1727 & 743 \\
\hline 2016 & 2381 & 1597 & 784 \\
\hline 2017 & 2651 & 1799 & 852 \\
\hline 2018 & 2883 & 2204 & 679 \\
\hline 2019 & 1605 & 1291 & 314 \\
\hline 2020 & 544 & 357 & 187 \\
\hline
\end{tabular}

Примітка: складено за даними [5]

Посилення торговельної напруги у світі пов'язано, перш за все, із діями Адміністрації США, коли за ініціативою Д.Трампа було впроваджено одностороннє підвищення тарифів, що спровокувало адекватне впровадження компенсаційних тарифів з боку Китаю, європейських країн, Канади, Мексики та інших. Як наслідок, такі дії спричинили зрушення не тільки бізнесу у торговельній сфері, значних змін набули й інвестиційні плани бізнесу, який відтерміновує їх реалізацію, що, у свою чергу, впливатиме на загальноекономічну динаміку. Все це дозволяє говорити про виникнення у світовому господарстві своєрідної спіралі, що характеризується, з одного боку появою нових компенсаційних торговельних тарифів, а з іншого - уповільненням інвестиційних потоків [3,c.5]. Продовження Д.Трампом політики економічного націоналізму призводить не тільки до поглиблення розриву торгівлі з Китаєм, більш вразливими стали транскордонні інвестиційні потоки та торгівля в цілому, при цьому торговельний баланс двосторонньої торгівлі ще більше погіршується (рис.1). Дефіцит торговельного балансу у 2018 році становив 419,2 млрд.дол. Посилення напруги між двома найбільшими акторами сучасної системи міжнародних економічних відносин за експертними оцінками може призвести до 600 млрд.дол. втрат для світової економіки в цілому [7].

Вплив політики на торговельну сферу залежить значною мірою від того, яким чином торгівля підпорядковується політичній стратегій, що реалізується урядом [8]. Для країн із малим економічним потенціалом зовнішньоторговельна безпека є важливішою складовою загальнонаціональної безпеки, і не $є$ обов'язковою для потужних країн. Тобто, відбувається певне розмежування між політикою та економікою одночасно із укріпленням торговельно-економічного співробітництва між потужними країнамипартнерами. 


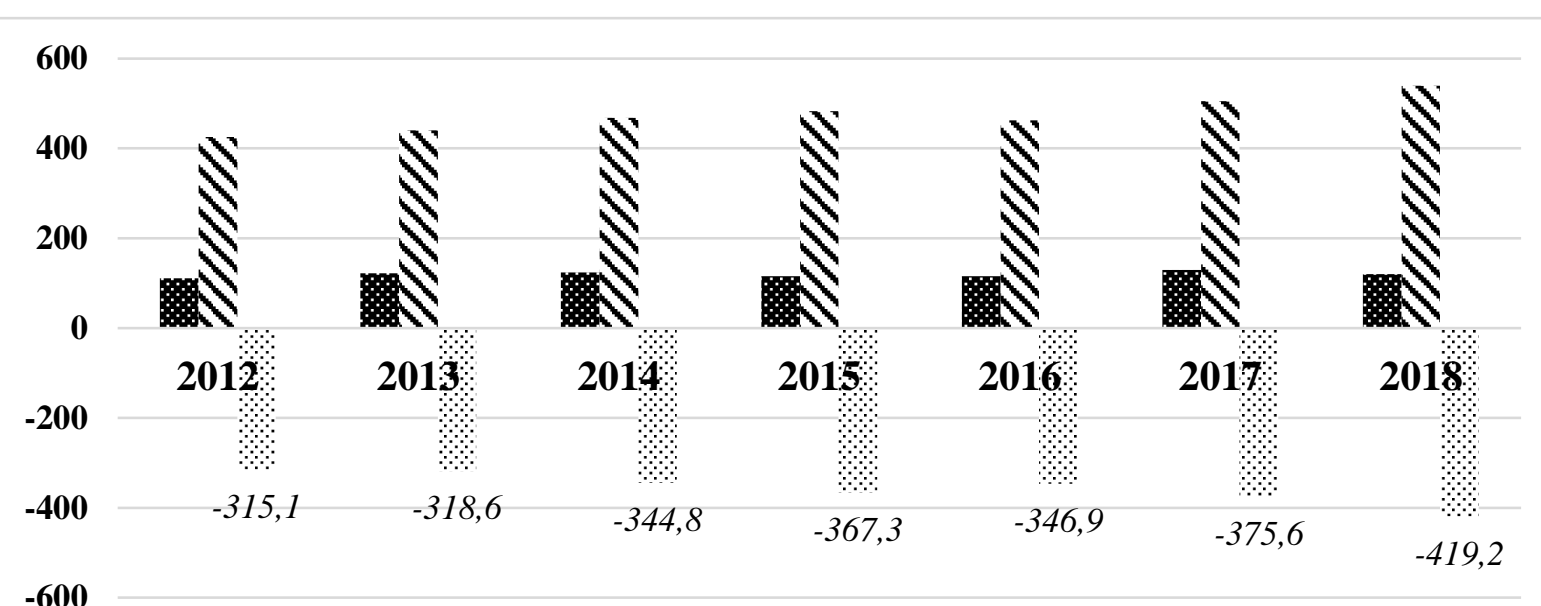

Експорт товарів, млрд. дол. \ Імпорт товарів, млрд. дол. Торговельний баланс, млрд. дол.

Рисунок 1. Динаміка зовнішньої торгівлі товарами США з Китаєм, млрд.дол.

Примітка: побудовано за даними [19]

Національна безпека кожної країни є важливою складовою у системі міжнародної безпеки в цілому, відповідно, наявність спільних інтересів визначатимете напрями міжнародного співробітництва країн, розвиток інтеграційної взаємодії між ними. Важлива роль у формування глобальної системи безпеки належить міжнародним організаціям, діяльність яких спрямована на гармонізацію взаємовідносин між країнами, трансформацію інтересів кожної країни у спільні (глобальні інтереси). Фактично, тільки шляхом міжнародного співробітництва можливе вирішення проблем, що набули транснаціонального масштабу, виникають у наслідок загроз нетрадиційного характеру[4,с.13-15], які викликають напруженість у соціумі, мають на нього мультикативний вплив. На Всесвітньому економічному форумі «Глобалізація 4.0: формування нової архітектури в епоху четвертої промислової революції» [17] підкреслювалось, що для побудови спільної архітектури глобального управління потрібні дві складові з боку міжнародного співтовариства: залучення всіх зацікавлених сторін до сталого діалогу, що матиме вирішальне значення, системного мислення, необмеженого короткостроковими інституційними та національними міркуваннями. Неприйняття такого нового підходу стане трагедією для людства.

Висновки. У сучасних реаліях розвитку світового господарства ризики посилюються, а колективні засоби врегулювання не спроможні їх вирішити. Посилення ризиків розвитку світового господарства трансформує торговельно-економічні політики країн, змінюються інструменти регулювання зовнішньої торгівлі задля забезпечення національних інтересів.

Односторонні зміни тарифного регулювання зовнішньої торгівлі, впроваджені 3 боку США, суттєво вплинули на торговельно-економічні відносини, а подальше посилення торговельної напруги призвело до значних руйнівних наслідків. Фактично, мова йде про розвиток багатостороннього механізму регулювання торговельноекономічних відносин в умовах невизначеності. Погіршення умов торговельноекономічної співпраці між країнами має довготривалу перспективу, посилюючи ризикові умови розвитку для усіх країн світу. 
У світі відбувається поширення ідей ліберального економічного патріотизму, спрямованого на забезпечення більшої незалежності, досягнення збалансованого економічного розвитку, покращення національного добробуту.

Зовнішньоторговельна складова безпеки залежить від ефективності зовнішньоторговельної діяльності країни, це, у свою чергу, значною мірою визначає умови формування рівня конкурентоспроможності. Достатньо високий рівень конкурентоспроможності $\epsilon$ передумовою формування безпекового середовища. Врахування конкурентних переваг та потенційних напрямів їх посилення дозволить забезпечити зростання рівня ефективності зовнішньоторговельної діяльності, формування достатнього рівня відкритості економіки, оптимального рівня іiі спеціалізації в системі міжнародного поділу праці, що в свою чергу сприятиме підвищенню рівня зовнішньоторговельної безпеки країни і визначатиме подальші наукові пошуки автора.

\section{Список використаної літератури}

1. Ağır S. B. Deepening of security conception and violent non-state actors as the challengers of human security / S. B. Ağır, N. M. Arman // Adnan Menderes University, Journal of Institute of Social Sciences. - 2014. - Vol. 1, Issue 1. - P. 105-116.

2. Beck U. Critical Theory of World Risk Society: A Cosmopolitan Vision / U. Beck // Constellations. - 2009. - Vol. 16, Issue 1. - C. 3-22.

3. Bollen J. Trade Wars: Economic impacts of US tariff increases and retaliations, an international perspective / J. Bollen, H. Rojas-Romagosa. - CPB Background Document, 2018. - 44 p.

4. Caballero-Anthony M. Understanding Non-traditional Security / M. Caballero-Anthony // Introduction to the Non-Traditional Security Studies. A Transnational Approach / M. CaballeroAnthony (ed.). - London : Sage Publications, 2016. - P. 3-19.

5. Global Trade Alert [Electronic resource] : official website. - Mode of access : https://www.globaltradealert.org/global_dynamics/area_all

6. Gunnella V. The economic implications of rising protectionism: a euro area and global perspective [Electronic resource] / V. Gunnella, L. Quaglietti // Economic Bulletin Articles. - 2019. Vol. 3. - Mode of access : https://hbr.org/2019/12/what-happens-when-antitrust-and-protectionismcycles-collide

7. Holland B. A $\$ 600$ Billion Bill: Counting the Global Cost of the U.S.-China Trade War [Electronic resource] / B. Holland, C. Sam // Bloomberg. - 2019. May 28. Mode of access : https://www.bloomberg.com/graphics/2019-us-china-trade-war-economic-fallout/?srnd=premiumeurope

8. Holsti K. Politics in command: Foreign trade as national security policy / K. Holsti // International organization. 1986. Vol. 40, № 3. - P. 643-671.

9. Global Risks Report 2017 [Electronic resource] : [Video] // World Economic Forum: official website. Mode of access : https://www.weforum.org/reports/the-global-risks-report-2017

10.Ilgen Th. Autonomy and Independence: US - Western European monetary and trade relations, 1958 - 1984 / Th. Ilgen. - New Jersey : Totowa, 1985. - 166 p.

11. Kaplan M. System and Process in International Politics / M. Kaplan. - Colchester : ECPR Press, 2006. - 252 p.

12. Morgenthau H. Truth and Power: Essays of a Decade, 1960-70 / H. Morgenthau. New York : Praeger Publishers, 1970. 449 p.

13. Nanto D. K. Economics and National Security: Issues and Implications for U.S. Policy [Electronic resource] / D. K. Nanto, Congressional Research Service // Federation of American 
Scientists. - 2011. - Mode of access : https://www.fas.org/sgp/crs/natsec/R41589.pdf (accessed 15 November 2014).

14. Olvey L. The economics of national security / L. Olvey, J. Dolden, R. Kelly. Waynes, N.J. : Avery Publishing Group, 1984. 404 p.

15. Protectionism in the 21st Century. National [Electronic resource] // Board of Trade Sweden. - Mode of access : https://www.kommers.se/In-English/Publications/2016/Protectionism-in-the-21stcentury/

16. Reznikova N. The Policy of Economic Nationalism: from Origins to New Variations of Economic Patriotism // N. Reznikova, V. Panchenko, O. Bulatova // Baltic Journal of Economic Studies. 2018. Vol. 4. № 4. P.274-281

17. Schwab K. Globalization 4.0 - what does it mean? [Electronic resource] / K. Schwab // World Economic Forum. - 2018. - 5 Nov. - Mode of access : https://www.weforum.org/agenda/2018/11/globalization-4-what-does-it-mean-how-it-will-benefiteveryone/ The GTA reports. Global Trade Alert: official website. URL: https://www.globaltradealert.org/reports

18. United States Census Bureau : official website. URL: www.census.gov

19. Walt St. The renaissance of security studies. International Studies Quarterly. 1991. Vol. 35, № 2. P. 211-239.

20. Панченко В. Г. Глобальні виміри неопротекціоніму: теорія і практика. Київ: Аграр Медіа Груп, 2018. 618 с.; Panchenko V. H. Hlobalni vymiry neoprotektsionimu: teoriia i praktyka. Kyiv: Ahrar Media Hrup, 2018. 618 s

21. Резнікова Н.В. Економічна неозалежність країн в умовах глобальних трансформацій: монографія. Київ: Аграр Медіа Груп, 2018. 460 с.; Reznikova N.V. Ekonomichna neozalezhnist krain $\mathrm{v}$ umovakh hlobalnykh transformatsii: monohrafiia. Kyiv: Ahrar Media Hrup, 2018. 460 s.

Стаття надійшла до редакції 26.02.2020

\section{O. I. Karpenko}

\section{GLOBALIZATION 4.0: \\ INTERNATIONAL TRADE AND NATIONAL SECURITY}

The article deals with the risks of international security, which were especially relevant in the fourth industrial revolution, with the emergence of new technologies (first of all digital and biological ones), the impact of which creates new challenges for the development of national economies, its security, environment, etc.

New dimensions of the influence of the countries of the world in the modern system of the world economy, influencing the transformation of the trade and economic policy of the countries are determined.

The author emphasizes that the national security of each country is an important component of the international security system as a whole, thus, the presence of common interests will determine the areas of international cooperation of the countries, the development of integration interaction between them. An important role in the formation of the global security system belongs to international organizations, whose activities are aimed at harmonizing relations between countries, the transformation of the interests of each country into common one (global interests).

The author proves that in the current realities of the development of world economy the risks are increasing, and collective means of settlement are not able to solve them. Increasing risks to the world economy transforms trade and economic policies of the countries, the instruments of foreign trade regulation for ensuring national interests change. 
The unilateral changes in the tariff regulation of foreign trade introduced by the United States have had a significant impact on trade and economic relations, and further intensification of trade tensions has led to significant devastating consequences. In fact, we are talking about the development of a multilateral mechanism for regulating trade and economic relations in conditions of uncertainty. Deterioration of the conditions of trade and economic cooperation between the countries has a long-term perspective, increasing the risky conditions of the development for all countries of the world.

The ideas of liberal economic patriotism, aimed at ensuring greater independence, achieving balanced economic development, and improving national welfare are spreading around the world.

The foreign trade component of security depends on the efficiency of the foreign trade activity of a country, which, in turn, largely determines the conditions for the formation of the level of competitiveness. A sufficiently high level of competitiveness is a prerequisite for the formation of a safe environment. Taking into account competitive advantages and potential directions of its strengthening will increase the efficiency of foreign trade, the formation of a sufficient level of openness of the economy, the optimal level of its specialization in the international division of labor, which in turn will increase foreign trade security and determine further scientific research.

Key words: globalization 4.0, international trade, national security, trade and economic policy, globalization.

УДК 339.727 .3

\section{P. А. Запотічна}

\section{СУЧАСНІ ОСОБЛИВОСТІ КРЕДИТНОЇ ДІЯЛЬНОСТІ ТНБ В УМОВАХ БОРГОВӦ̈ ЕКОНОМІКИ}

Статтю присвячено дослідженню зрушень, що відбуваються у напрямах та формах кредитної діяльності транснаціональних банків, $і$ обтрунтуванню впливу операчій ТНБ з прямого кредитування на формування боргової економіки в крайнах світу. Проаналізовано динамічні і структурні зміни, що спостерігаються у кредитуванні ТНБ країн-рецииієнтів, та визначено причини ции змін. Особливу увагу приділено дослідженню особливостей прямого кредитування, яке потенційно може призводити до формування боргової економіки у краӥни-реципієнта, та оцінці його структури за терміном погашення, типом та регіональною приналежністю позичальника. На основі аналізу розрахованих відносних показників зовнішнього боргу та прямих кредитів для окремих розвинутих країн і краӥн, щзо розвиваються, з різних регіонів світу визначено, щуо економіки провідних розвинутих краӥн належать до боргового типу. Група крайн, що розвиваються, $\epsilon$ диференційованою $і$ включає як боргові, так $і$ неборгові економіки. Встановлено, щуо у переважній більшості розвинутих країн та частині країн, що розвиваються, кредитування з боку ТНБ досі залишається важливим джерелом формування боргової економіки.

Ключові слова: кредитна діяльність транснащіональних банків, прямі і непрямі кредити, зовнішні запозичення, боргова економіка, зовнішня заборгованість.

DOI 10.34079/2226-2822-2020-10-19-56-65 